Hum. Dev. 1977;20:317-325

\title{
In memoriam Klaus F. Riegel
}

\section{November 6, 1925-July 3, 1977}

It is with great sorrow that we note the death of Klaus F. Riegel on July 3, 1977 at his home in Ann Arbor at the age of 51. Klaus wrote in a recent paper that no individual can work in isolation from the efforts of countless others, so that a discussion of work and labor necessarily converges upon the topic of social cooperation and, ultimately, of love. It was in this spirit that Klaus interacted with his many students, who will remember him as a kind, patient, and generous teacher, always willing to listen and encourage. His office, as well as his home, were havens for several generations of students, who found their widely divergent ideas not only tolerated but also clarified and strengthened. In the scholarly and sociable atmosphere which Klaus created, they learned much both from him and with him. His colleagues will recall his unrelenting energy in contributing to the growth of developmental psychology and in motivating others with his enthusiasm and insights. Many will regard it as an honor to have entered into dialogue with him. After earning Ins MA at the University of Minnesota in 1955 and his $\mathrm{PhD}$ at the University of Hamburg in 1958, Klaus Riegel spent a postdoctoral year as a Visiting Scientist at the National Institute of Health. He joined the faculty of the Department of Psychology at the University of Michigan in 1959, where he was a participant in the Psycholinguistics Program, the Institute of Gerontology, and the Center for Human Growth and Development. He was the author or editor of many books, and a regular contributor to the journal literature in his several areas of interest, including the development and assessment of intellectual functions of the aged, psycholinguistics, and the history and philosophy of the social sciences. A member of many professional organizations, Klaus was elected as a fellow in both the Gerontological Society and the American Psychological Association. He also served on the Executive Committee of the International Society for the Study of Behavioral Development, and as president of the Psychological and Social Sciences Section of the Gerontological Society. In In memoriam Klaus F. Riegel 


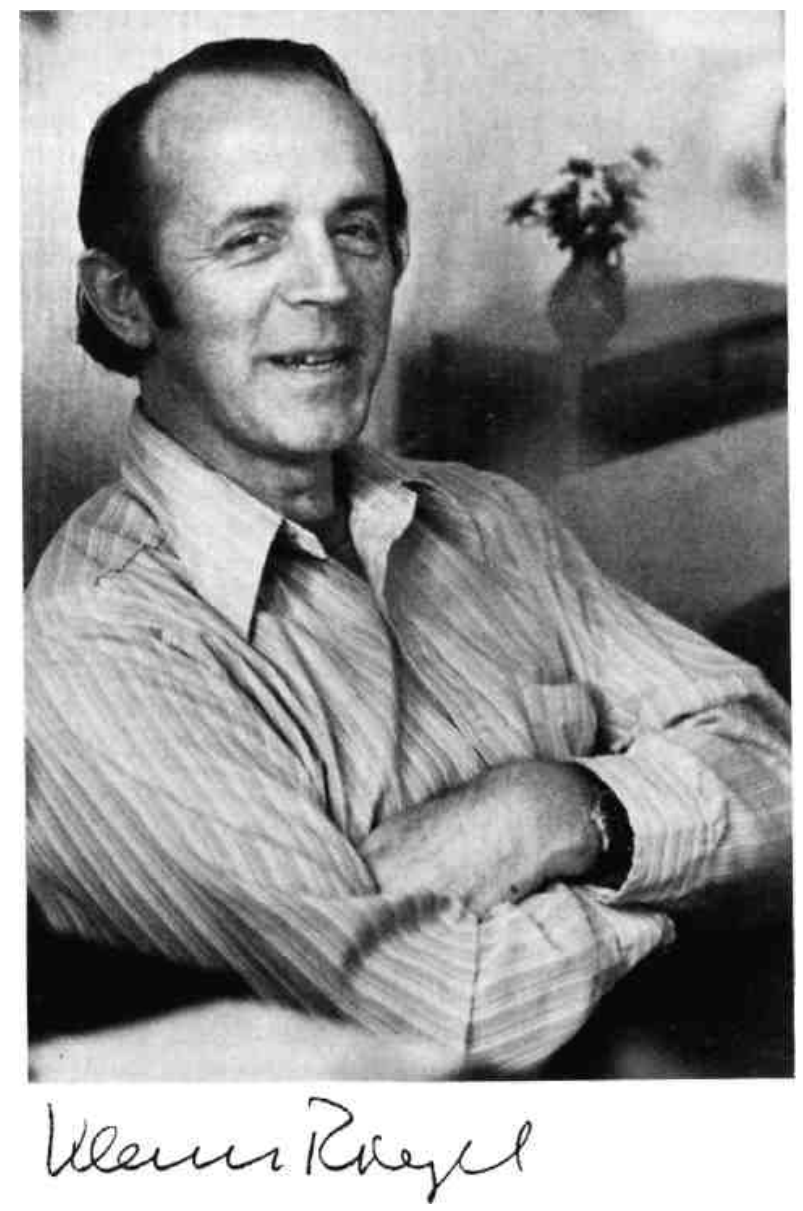

1976, the Gerontological Society recognized Klaus Riege $\Gamma$ s contributions by presenting him with the Robert W. Kleemeier Award. He also contributed greatly to the growth and increasing eminence of Human Development, as its editor from 1970 onward.

In recent years, Klaus Riegel labored unceasingly towards the formulation of a dialectical psychology, through his own writing and lecturing and also through annual conferences held successively at Rochester, Toronto, Cape Cod, and, in 1977, at Shimer College. Dialectical psychology, as he perceived it, focuses upon the understanding of activities and changes rather than static traits and balanced equilibria, and recognizes the necessary interdependence of developmental changes in the individual with historical changes in the society. Klaus's conceptualization is an unusual and a significant one for psychology, emphaIn memoriam Klaus F. Riegel

319

sizing that dialectics can be and ought to be applied to the discipline itself. In this way, a history of interpretations in psychology is described, appropriate to the succession of historical changes in the society. Thus, Klaus's work has set psychology on a new and unpredictable course, by helping us to become aware of our own development as a discipline.

From a dialectical perspective it can be seen that Klaus's efforts should not endure unchallenged and without further interpretations, for this would mean that no one had answered the dialogue which he initiated in his writings. Rather, Klaus's work provides the context from which new and even more radical interpretations in psychology will be constructed. The premature death of Klaus Riegel is a great loss to his many devoted students and colleagues and to the discipline. 
Scientific Contributions

1956 Riegel, K.F.: Statistische Methoden für Psychologen und Pädagogen. (Book review.) Psychol. Beitr. 2: 642-645 (1956). Bondy, C. and Riegel, K.F.: Social psychology in Western

Germany (Library of Congress,

Washington, D.C. 1956). Wechsler, D.: Die Messung der Intelligenz Erwachsener (Huber, Bern 1956).

1957 Riegel, K.F.: On the interrelationship of certain social attitudes in old age. Proc. 4th Int.

Congr. Gerontol., Merano 1957, pp. 512-515. Riegel, K.F.: Über den differentiellen Abbau

einiger intellektueller Funktionen in den

höheren Altersstufen. Proc. Int. Symp., Aspects of Senile Nervous Diseases, Venice

1957, pp. 238-243. Riegel, K.F.: Über den differentiellen Abbau sprachgebundener Funktionen in den höheren

Altersstufen. Bericht 21. Kongr. dt. Ges. Psycho 1., Bonn 1957, pp. 240-248.

1958 Riegel, K.F.: Die Bedeutung der Statistik für das psychologische Experiment. Psychol.

Beitr.

3: 595-618(1958). Riegel, K.F.: Ergebnisse und Probleme der psychologischen

Alternsforschung. Teil I. Vita

Humana 1: 52-64, 111-127 (1958). Riegel, K.F.: Ergebnisse und Probleme der psychologischen

Alternsforschung. Teil II. Vita

Humana 1: 204-243 (1958).

1959 Riegel, K.F.: A study on verbal achievements of older persons. J. Gerontol. 14: 453-456

(1959). Riegel, K.F.: Ergebnisse und Probleme der psychologischen Alternsforschung. Teil III.

Vita

Humana 2: 213-237 (1959). Riegel, K.F.: Personality theory and aging; in Birren Aging and the individual, pp. 797-851

(University of Chicago Press, Chicago 1959). Riegel, R.M, und Riegel, K.F.: Standardisierung des Hamburg-Wechsler-Intelligenztests für

Erwachsene (HAWIE) für die Altersstufen über 50 Jahre. Diagnostica 5: 97-128

(1959).

In memoriam Klaus F. Riegel

320

1960 Riegel, K.F.: Attitude changes in old age. Proc. 16th Int. Congr. Psychol., Bonn 1960, pp. 142-147. Riegel, K.F. and Riegel, R.M.: A study on changes of attitudes and interests during later

years of life. Vita Humana 3: 177-206 (1960). Riegel, K.F. and Riegel, R.M.: The analysis of objective parameters in word recognition

experiments. Proc. 16th Int. Congr. Psychol., Bonn 1960, pp. 798-799. Birren, J.E. and Riegel,

K.F.: On choice reaction time and age. Proc. 5th Int. Congr.

Gerontol., San Francisco 1960.

1961 Riegel, K.F. and Riegel, R.M.: Prediction of word-recognition thresholds on the basis of stimulus-parameters. Lang. Speech 4: 157-170 (1961).

1962 Riegel, K.F.: Zur wissenschaftlichen und methodischen Grundlage des psychologischen

Test-

verfahrens - Möglichkeiten und Grenzen. Studium Generale 75/ 89-112 (1962). Riegel, K.F. and Riegel, R.M.: Analysis of differences in test performance and item difficulty between young and 
old adults. J. Gerontol. 17: 97-105 (1962). Riegel, K.F.; Riegel, R.M. und Skíba, G.: Untersuchung der Lebensbedingungen, Gewohnheiten und Anpassung älterer Menschen in Norddeutschland. Vita Humana 5: 204-247 (1962). Riegel, K.F.; Riegel, R.M., and Wendt, D.: Perception and set. A review of the literature and

a study on the effects of instructions and verbal habits on word recognition thresholds of young and old subjects. Acta psychol. 12: 224-251 (1962). Birren, J.E. and Riegel, K.F.: Age differences in response speed as a function of controlled

variations of stimulus conditions; lights, numbers, letters, colors, syllables, words, and word relationships; in Tibbits and Donahue Social and psychological aspects of aging, pp. 751-758 (Columbia University Press, New York 1962). Birren, J.E.; Riegel, K.F., and Morrison, D.F.: Age difference in response speed as a function of controlled variations of stimulus conditions. Evidence of a general speed factor. Gerontologica 6: 1-18 (1962). Birren, J.E.; Riegel, K.F., and Robbin, J.S.: Age differences in continuous word associations measured by speech recordings. J. Gerontol. 17: 95-96 (1962). Riegel, R.M. and Riegel, K.F.: A comparison and reinterpretation of factorial structures of the W-B, the WAIS, and the HAWIE on aged persons. J. consult. Psychol. 26: 31-37 (1962).

1963 Riegel, K.F. and Riegel, R.M.: An investigation into denotative aspects of word meaning. Lang. Speech 6: 5-21 (1963). Riegel, K.F.; Riegel, R.M., and Meyer, G.: The prediction of intellectual development and death. A longitudinal analysis. Proc. 6th Int. Congr. Gerontol., Copenhagen 1963, p. 194. Birren, J.E.; Riegel, K.F., and Morrison, D.F.: Intellectual capacities, aging, and man's environment; in Williams, Tibbits and Donahue Processes of aging, vol. 1, pp. 9-44 (Atherton Press, New York 1963).

1964 Riegel, K.F. and Riegel, R.M.: Changes in associative behavior during later years of life. A cross-sectional analysis. Vita Humana 7: 1 - 32 (1964).

In memoriam Klaus F. Riegel

321

1965 Riegel, K.F.: A French nosegay. (Book review.) Contemp. Psychol. 10: 26-28 (1965). Riegel, K.F.: Age and cultural differences as determinants of word associations. Suggestions for their analysis. Psychol. Rep. 16: 75-78 (1965). Riegel, K.F.: fr = const. (Book review.) Contemp. Psychol. 10: 388-389 (1965). Riegel, K.F.: Speed of verbal performance as a function of age and set. A review of issues

and data; in Welford and Birren Behavior, aging, and the nervous system, pp. 150-190

(Thomas, Springfield 1965). Riegel, K.F.: The role of longitudinal research in gerontology, psychological aspects. Colloquium on longitudinal studies, pp. 91-94 (National Institute of Child Health and

Human Development, Bethesda 1965). Riegel, K.F. and Birren, J.E.: Age differences in associative behavior. J. Gerontol. 20:

125-130(1965). Riegel, K.F. und Riegel, R.M.: Vorschläge zu einer statistischen Interpretation von Alterns-

veränderungen sprachlicher Leistungen; in Hardesty und Eyferth Forderungen an die Psychologie, pp. 87-105 (Huber, Bern 1965).

1966 Riegel, K.F.: Cross-cultural comparisons of denotative meaning; in General problems of 
psychology. Proc. 18th Int. Congr. Psychol, Moscow 1966, p. 341. Riegel, K.F.: Development of language. Suggestions for a verbal fallout model. Hum. Dev. 9:

97-120 (1966). Riegel, K.F.: Longitudinal research. The Northern German study. Proc. 7th Int.

Congr.

Gerontol., Vienna 1966, pp. 155-159. Riegel, K.F. and Birren, J.E.: Age differences in verbal associations. J. genet. Psychol. 108:

153-170(1966). Riegel, K.F.; Riegel, R.M., and Levine, R.S.: An analysis of associative behavior and creativity. J. Pers. soc. Psychol. 4: 50-56 (1966). Gekoski, W.L. and Riegel, K.F.: A study of the one-week stability of the Michigan restricted

association norms. Psychol. Rep. 18: 397-398 (1966).

1967

Riegel, K.F.: Der sprachliche Leistungstest SASKA (Verlag für Psychologie, Göttingen 1967).

Riegel, K.F.: Psycholinguistics; in Eggenberger Yearbook of science and technology, pp. 316-

318 (McGraw Hill, New York 1967).

Riegel, K.F. and Birren, J.E.: Age differences in choice reaction times to verbal stimuli.

Gerontologia 13: 1-13 (1967).

Riegel, K.F.; Ramsey, R.M., and Riegel, R.M.: A comparison of first and second languages of American and Spanish students. J. verb. Learn, verb. Behav. 6: 536-544 (1967).

Riegel, K.F.; Riegel, R.M., and Meyer, G.: A study of the drop-out rates in longitudinal research on aging and the prediction of death. J. Pers. soc. Psychol. 4: 342-348 (1967).Reprinted in

Neugarten, B.L.: Middle age and aging, pp. 563-570 (University of Chicago Press, Chicago 1968). Also in Sarason, I.G.: Contemporary research in personality, pp. 240-248 (Van Nostrand, New York 1969).

Riegel, K.F.; Riegel, R.M., and Meyer, G.: Socio-psychological factors of aging. A cohortsequential analysis. Hum. Dev. 10: 27-56 (1967).

Gekoski, W.L. and Riegel, K.F.: A study of the one-year stability of the Michigan restricted association norms. Psychonom. Sci. 8: 427-428 (1967).

In memoriam Klaus F. Riegel

322

1968 Riegel, K.F.: Changes in psycholinguistic performances with age; in Talland Human behavior

and aging, pp. 239-279 (Academic Press, New York 1968). Riegel, K.F.: Comparison of restricted associations among six languages. J. soc. Psychol. 75:

67-78(1968). Riegel, K.F.: Effects of socio-cultural and biological conditions upon linguistic and cognitive

functioning of aged persons. Partially reproduced in Perspectives on human deprivation, pp. 123125, 151-153, 159-162 (National Institute of Child Health and Human Development, Bethesda 1968). Riegel, K.F.: Ergebnisse und Probleme der psychologischen Alternsforschung; in Thomae und Lehr Altern: Probleme und Tatsachen, pp. 142-170 (Akademische Verlagsgesell-

schaft, Frankfurt 1968). Riegel, K.F.: Some theoretical considerations of bilingual development. Psychol. Bull. 70:

647-670(1968). Riegel, K.F.: Untersuchungen sprachlicher Leistungen und ihrer Veränderungen. Z. allg.

angew. Psychol. 15: 649-692 (1968). Riegel, K.F.; Riegel, R.M., and Meyer, G.: The prediction of retest-resisters in longitudinal 
research on aging. J. Gerontol. 23: 370-374 (1968). Riegel, K.F.; Riegel, R.M.; Quarterman, C.J., and Smith, H.E.: Developmental differences in

word meaning and semantic structure. Hum. Dev. 11: 92-106 (1968). Riegel, K.F.; Riegel, R.M., and Skiba, G: Probleme der Anpassung im Alltag; in Thomae und

Lehr Altern: Probleme und Tatsachen, pp. 505-516 (Akademische Verlagsgesellschaft, Frankfurt 1968). Chown, S. and Riegel, K.F.: Psychological functioning of normal aging and senile aged

(Karger, Basel 1968). Quarterman, C.J. and Riegel, K.F.: Age differences in the identification of concepts of the

natural language. J. exp. Chüd Psychol. 6: 501-509 (1968).

1969 Riegel, K.F.: History as a nomothetic science. Some generalizations from theories and research in developmental psychology. J. soc. Iss. 25: 99-127 (1969). Riegel, K.F.: Research design in the study of aging, and the prediction of retest resistance

and death. Proc. 8th Int. Congr. Gerontol., Washington 1969, pp. 455-457. Riegel, K.F.: The ecology of bilingual development. Proc. Council Aging Hum. Dev.,

Durham 1969, pp. 69-74. Zivian, M.T. and Riegel, K.F.: Word identification as a function of semantic clues and

associative frequency. J. exp. Psychol. 79: 336-341 (1969).

1970 Riegel, K.F.: A structural, developmental analysis of the Department of Psychology at the University of Michigan. Hum. Dev. 13: 269-279 (1970). Riegel, K.F.: Relational interpretation of the language acquisition process; in Flores d'Arcais

and Levelt Advances in psycholinguistics, pp. 224-236 (North Holland, Amsterdam 1970). Riegel, K.F.: The language acquisition process. A reinterpretation of selected research findings; in Goulet and Baltes Life-span developmental psychology. Research and theory, pp. 357-399 (Academic Press, New York 1970). Lacher, M.R. and Riegel, K.F.: Visual recognition thresholds for nouns as a function of instruction, type of word relation and associative strength. J. gen. Psychol. 83: 23-33

(1970).

In memoriam Klaus F. Riegel

323

Stern, E.J. and Riegel, K.F.: Comparisons of the restricted associations of chronic schizophrenic and normal control subjects. J. abnorm. Psychol. 75: 164-171 (1970).

1971 Riegel, K.F.: The prediction of death and longevity in longitudinal research; in Palmore and Jeffers Prediction of life-span, pp. 139-152 (Heath Lexington Books, Lexington 1971). 1972 Riegel, K.F.: Allgemeine Alternspsychologie; in Psychiatrie der Gegenwart; 2. Aufl., vol. 2 ,

pp. 977-1000 (Springer, Berlin 1972). Riegel, K.F. and Riegel, R.M.: Development, drop and death. Devi Psychol. 6: 306-319

(1972). Riegel, K.F.: On the history of psychological gerontology; in Eisdorfer and Lawton Psychology of adult development and aging, pp. 37-68 (American Psychological Association, Washington 1972). Riegel, K.F.: The changing individual in the changing society; in Monks, Hartup and deWit

Determinants of behavioral development, pp. 239-257 (Academic Press, New York 1972). Riegel, K.F.: The inñuence of economic and political ideologies upon the development of developmental psychology. Psychol. Bull. 78: 129-141 (1972). Riegel, K.F.: Time and change in the development of the individual and society; in Reese 
Advances in child development and behavior, vol. 7, pp. 81-113 (Academic Press, New York 1972). Riegel, K.F.: On the dialectics of cognitive development. Proc. 9th Int. Congr.

Gerontol.,

Kiev 1972, pp. 308-311. Riegel, K.F. and Zivian, I.W.M.: A study of inter- and intra-lingual associations in English

and German. Lang. Learning 22: 51-63 (1972).

1973 Riegel, K.F.: An epitaph for a paradigm. Hum. Dev. 16: 1-7 (1973). Riegel, K.F.: Cardinal

Chomsky's platonic revival movement or linguistics out of HIS mind.

A rejoinder to Professor Weimer's paper. Am. Psychol. 28: 1013-1016 (1973). Riegel, K.F.:

Developmental psychology and society. Some historical and ethical considerations; in

Nesselroade and Reese Life-span developmental psychology. Methodological

issues, pp. 1-23 (Academic Press, New York 1973). Riegel, K.F.: Dialectic operations. The final period of cognitive development. Hum. Dev.

16: 346-370(1973). Riegel, K.F.: Intelligence. Alternative views of a paradigm (Karger, Basel

1973). Riegel, K.F.: Language and cognition. Some life-span developmental issues.

Gerontologist

13: 478-488 (1973). Riegel, K.F.: Systems and structure. Essays in communication and exchange. (Book review.)

Psychol. Today 7: 9-15 (1973). Riegel, K.F: The recall of historical events. Behav. Sci. 18: 354363 (1973).

1974 Riegel, K.F.: The structure of the structuralists. (Book review.) Contemp. Psychol. 19: 811813(1974).

In memoriam Klaus F. Riegel

324

1975

Riegel, K.F.: Adult life crises. Toward a dialectic theory of development; in Datan and Ginsberg Life-span developmental psychology. Normative life crises, pp. 97-124 (Academic Press, New York 1975).

Riegel, K.F.: A manifesto for dialectical psychology; in Riegel The development of dialectical operations, pp. 239-241 (Karger, Basel 1975). Also in Dialect. Psychol. Newsletter 1 (1975).

Riegel, K.F.: On the dialectics of the dialectics. Dialect. Psychol. Newsletter 1: 2-3 (1975).

Riegel, K.F.: Semantic basis of language. Language as labor; in Riegel and Rosenwald Structure and transformation. Developmental and historical aspects, pp. 167-192 (Wiley, New York 1975). Riegel, K.F.: Structure and transformation in modern intellectual history; in Riegel and

Rosenwald Structure and transformation. Developmental and historical aspects, pp. 3-24 (Wiley, New York 1975).

Riegel, K.F.: Subject-object alienation in psychological experiments and testing. Hum. Dev. 18: 181-193 (1975). Also in Riegel The development of dialectical operations, pp. 181-193 (Karger, Basel 1975).

Riegel, K.F.: The development of dialectical operations (Karger, Basel 1975).

Riegel, K.F.: Toward a dialectic theory of development. Hum. Dev. 18: 50-64 (1975). Also in

Riegel The development of dialectical operations, pp. 50-64 (Karger, Basel 1975).

Riegel, K.F. and Angleitner, A.: The pooling of longitudinal studies in the psychology of aging. Aging Hum. Dev. 6: 57-66 (1975).

Riegel, K.F. and Rosenwald, G.C.: Structure and transformation. Developmental and historical aspects. (Wiley, New York 1975). 
1976 Riegel, K.F.: All the trouble with linguistics. A psycholinguistic critique. Int. J. Psycholing. 1: 95-104(1976). Riegel, K.F.: A note on the modifiability and reversibility of development and aging. Aging

Hum. Dev. 7: 269-272 (1976). Riegel, K.F.: Dialectical operations. The final period of cognitive development; inRychlak

Dialectic. Humanistic rationale for behavior and development, pp. 60-71 (Karger,

Basel 1976). Riegel, K.F.: From traits and equilibrium toward developmental dialectics; in Arnold and

Cole 1974-75 Nebraska Symposium on motivation, pp. 349-407 (University of

Nebraska Press, Lincoln 1976). Riegel, K.F.: History of psychological gerontology; in Birren and Schaie Handbook of the psychology of aging, pp. 70-102 (Van Nostrand Reinhold, New York 1976). Riegel, K.F.: The dialectics of human development. Am. Psychol. 31: 689-700 (1976). Riegel, K.F.: The psychology of development and history (Plenum Press, New York 1976). Riegel, K.F.: The systematization of dialectical logic for the study of development and change. An introduction. Hum. Dev. 19 (1976). Riegel, K.F. and Freedle, R.O.: What does it take to be bilingual or bidialectical? in

Harrison and Trabasso A seminar in Black English, pp. 25-44 (Erlbaum Associates, Washington 1976). Riegel, K.F. and Meacham, J.A.: The developing individual in a changing world. General and

historical issues, vol. I (Mouton, The Hague 1976). Riegel, K.F. and Meacham, J.A.: The developing individual in a changing world. Social and cultural issues, vol. II (Mouton, The Hague 1976).

In memoriam Klaus F. Riegel

325

Riegel, K.F.: Some theoretical considerations of subcultural differences in language development; in Riegel and Meacham The developing individual in a changing world. General and historical issues, vol. I, pp. 375-385 (Mouton, The Hague 1976).

1977 Riegel, K.F.: Past and future trends in gerontology. Gerontologist 1 7: 105-113 (1977).

Riegel, K.F.: Psychology and the future; in Wertheimer Issues. Psychology and the problems of today (Discussant's comment.) (Scott, Foresman, Glenview 1977). Riegel, K.F.: The dialectics of time; in Datan and Reese Life-span developmental psychology. Dialectical perspectives on experimental research (Academic Press, New York

1977). Riegel, K.F.: Toward a dialectical interpretation of time and change; in Gorman and Wess-

man The personal experience of time (Plenum Press, New York 1977). Riegel, K.F.: Zeit und Veränderung in der Entwicklung des Individuums und der Gesellschaft; in Rosenmeyer Die Lebensalter: Kontinuität und Krisen (Piper, München 1977). Broughton, J.M. and Riegel, K.F.: Developmental psychology and the self. Ann. N.Y. Acad.

Sci. 297: 149-167 (1977). Meacham, J.A. and Riegel, K.F.: Dialectical perspectives on Piaget's theory; in Steiner Piaget and beyond. VII. The psychology of the 20th century (Kindler, Zurich 1977). In Press Riegel, K.F.: Dialectical psychologists unite. You have nothing to fear but the dogmatism of 
R.W. Connell's Marxism. Merrill-Palmer Q. Riegel, K.F.: Three paradigms of developmental psychology; in Buss The social context of

psychological theory. Toward a sociology of psychological knowledge (Irvington, New

York). Riegel, K.F.: Psychology mon amour. A countertext (Houghton-Mifflin, Boston). Riegel,

K.F. and Meacham, J.A.: Dialectics, transaction, and Piaget's theory; in Pervin and

Lewis Internal and external determinants of behavior (Plenum Press, New York).

In Preparation Riegel, K.F.: Labor and love. Some dialectical commentaries; in Smelser and Erikson Love

and work in adulthood. Riegel, K.F.: Foundations of dialectical psychology (Klett, Stuttgart). Riegel, K.F.: The development of meaning. A dialectical interpretation.

The Members of the Editorial Board and Publisher of 'Human Development' heard with great sorrow of the death of Prof. Klaus Riegel. Since he joined the Editorial Committee and took over the responsibility as the Managing Editor, he contributed very much to the progress of this Journal. His emphasis on theoretical contributions gave a very distinct character to the Journal and made it a well-known instrument for the exchange of information in the field of behavioral development.

His efforts and achievements will always be remembered.

Editorial Board and Publisher of 'Human Development' 